\title{
PSYCHOLOGICAL ACTIVITIES IN ASIAN COUNTRIES
}

\section{- LETTERS FROM ASIAN COLLEAGUES -}

Before attending the International Congress of Psychology in Washington, D. C., I sent letters of inquiry to our Asian colleagues about the recent status of psychological activities in their countries, as the only one member of the Executive Committee of the International Union of Scientific Psychology from Asia. Most of them kindly gave me informations, which I am going to print in the following in alphabetical order of the region. The letter from Professor Pan of Peking was written in Chinese and was translated into English, but all others are original.

Koji Sato, the Editor.

\section{CEYLON}

From Professor J.E. Jayasuriya, Peradeniya :

Dear Professor Sato,

15th July 1963

Thank you for your letter of 5th July. There is no national psychological association in Ceylon. The number of psychologists in Ceylon is not more than three or four.

I hope you would have a pleasant and profitable journey abroad and return with redoubled enthusiasm to continue the good work you are doing through $P_{s y c h o l o g i}$.

Yours sincerely,

J. E. Jayasuriya

Professor of Education

Head: Department of Education

University of Ceylon

\section{CHINA}

From Professor PAN Shuh, Peking:

Professor Sato Koji:

Recently psychological activities of our country have made a remarkable progress, and, especially under the situation of the Great Jump, psychological activities have become connected to a great extent with the practical fields such as education, medicine as well as labor, and at the same time have developed studies of fundamental theories of psychology. Psychology is just for the service to the socialistic construction of our contintry, and has attained first steps of achievement; correspondingly the ranks of psychologists of our country are being expanded day by day. In order to promote the development of psychological activities, we sincerely hope to exchange publications and also exchange work experiences, regardless of their politics and religions. Unfortunately the International Congress of Psychology follows the American imperialism and regards the Chinese people's behavior with hostility and is working as an instrument for the strategy of making two Chinas, and therefore we are obliged to refuse to participate in the activities of the International Congress of Psychology.

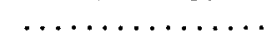

1963 VII 20
Institute of Psychology, Academia Sinica, Director Pan Shuh (潘菽)

(Translated from the Chinese by Koji Sato) 


\section{From Professor Hsiang-Yu SU, Taipei:}

Dear Professor Sato:

July 20, 1963

It is my great pleasure to know by your letter of July 5 , that you are going to attend the International Congress of Psychology. I am glad to inform you that I am going to attend, too. I will take off for Tokyo on early August. After stay of couple of days at each stop in Japan and San Francisco, I will arrive at Washington on July 19.

In regard to your questions, may I answer:

1. The National Psychological Association in China was set up last spring, of which $I$ am the chairman, since the day is so short that there are no activities which is deserved to tell.

2. We hope to join the International Union of Scientific Psychology in near future.

3. Psychologists in this country is less than one hundred.

4. We hope a good connection between the International Union and the Psychological Association of China.

Thanks you, Looking forward to see you in Washington D.C.

Sincerely yours,

$$
\begin{aligned}
& \text { Hsiang-Yu Su (倞鄉椭) } \\
& \text { Department of Psychology } \\
& \text { National Taiwan University }
\end{aligned}
$$

Note: In People's China the name is written in Western Linnguages in the order of Family Name-Given Name, while in China Republic in the order of Given Name-Family Name. The order in the original Chinese language is Family Name-Given Name, and it is the same in Japanese.

\section{HONGKONG}

From Dr. K. Kvan, Hongkong:

Dear Professor Sato,

1st August 1963

Dr. P. M. Yap of the Mental Hospital has forwarded your letter regarding the state of affairs with regard to Psyclology in Hong Kong to me with a note suggesting that I may wish to write you also.

I do not think I have nuch to add to Dr. Yap's letter. As you will know we have no psychological association in Hong Kong. I suppose there are about 12 - 14 psychologists here; there are undoubtedly more who have a degree in Psychology but the dozen includes those who are actively engaged in research or in teaching of Psychology.

I expect we shall form a society in the near future-and that the XVIII Congress will be held in Asia allowing for greater participation from Hong Kong. Indeed it would be quite possible to hold the Conference here. The only drawback would be the absence of psychological services for field trips-apart from our new Mental Hospital-but from the organizational aspect and with regard to accomodation of all classes, from University Halls to Luzury hotels, Hong Kong is fully capable of staging a conference. Transport from all parts is easily available and a Conference of this magnitude could certainly find a ready welcome from Government and University.

Perhaps you would care to consider presenting this viewpoint at the Conference in Washington. I expect Mrs. Anita Li, a Child Guidance Specialist, to be at the Conference and she should be able to give any supporting details you may need.

Yours sincerely,

\section{E. Kvan}

Lecturer in Psychology Department of Philosophy University of Hongkong 


\title{
INDIA
}

From Professor S. Sinha, Calcutta:

My Dearest Friend,

July 24, 1963

I am adding the reply of your questionnaires:

1. Present status of our national psychological association is not bright from the pecuniary condition, although there is increasing demand of psychologists in many of the fields in India.

2. Yes, I would like very much to join the U. Sc. Psy. in near future, as I am getting much experiences of the Psychologists of India and others by editing the books as referred above.

3. The number of psychologists in India has grown 100 times from last 15 years.

4. I shall be pleased if International Union recognizes our association as a scientific body as it has been legally registered body, since my time and help in the matter of money and membership.

5. Is it possible to enroll members through A. P. A. if we agree to give concession to the members of A. P. A. or Union? We want to develop communication and research activities amongst the Asian Psychologists.

With sincerest and kindest regards,

\author{
Sincerely yours, \\ Dr. S. Sinha, M. S., Ph. D. \\ Department of Psychology \\ Calcutta University
}

\section{From Professor P.H. Prabhu, Ahmedabad:}

Answers to Professor Koji Sato's queries

I. There are two national organizations of psychologists in India:

(1) The Indian Psychological Association (c/o Department of Psychology, University College of Science, 92 Upper Circular Road, Calcutta 9); and

(2) The Indian Academy of Applied Psychology (c/o Professor C. R. Paramesh, Secretary, IAAP, Presidency College, Madras, India).

(1) The Indian Psychological Association: The headquarters of this Association are at Calcutta in the east (which is about 1200 miles from Bombay in the west, about 1000 miles from Madras in the south and about 900 miles from Delhi in the north). Because of this difficulty of communication, and the Executive Committee meetings being held in Calcutta, almost all the Committee members are from Calcutta. It has on its roll only about 95 members (as on April 26, 1963).

(2) The Indian Academy of Applied Psychology: The headquarters of this Association are in Madras. But it has five regional branches, as follows:

Region I: States of Andhra Pradesh, Kerala, Dadras, Mysore, Pondicherry, Andaman and Nicobar;

II: States of Gujarat, Maharashtra and Goa;

III: States of Assam, Bihar, Manipur, Tripura, and West Bengal;

IV: States of Madhya Pradesh, Crissa and Uttar Pradesh.

V: States of Delhi, Himachal Pradesh, Jammu and Kashmir, Panjab and Rajasthan. 
Each Region has a President.

This Association has also enlisted the support of many Indian Universities by having a number of Vice-Chancellors as its honorary patrons. It holds symposia on important topics from time to time, inviting psychologists from various parts of the country to participate. On the whole it has been very active.

II. Both these national organizations deserve to be affiliated in the International Union of Scientific Psychology-one is an overall organization, the other is a more specialized organization.

III. According to the latest information available there are about 504 psychologists in India working in the following areas:

Number of psychologists according to special interests:

There will be many cases of overlap in these interests, since an individual may have more than one interest.

$\begin{array}{rccc}\text { Branch of Psychology } & \text { First Preference } & \text { Second } & \text { Third } \\ \text { i. Experimental } & 28 & 23 & 24 \\ \text { ii. Comparative } & 4 & 10 & 7 \\ \text { iii. Physiological } & 6 & 6 & 10 \\ \text { iv. Clinical } & 42 & 27 & 26 \\ \text { v. Personality } & 48 & 25 & 20 \\ \text { vi. Social } & 58 & 46 & 44 \\ \text { vii. Industrial } & 31 & 33 & 28 \\ \text { viii. Educational (including } & & & \\ \text { guidance, counselling, etc.) } & 70 & 58 & 27 \\ \text { ix. Child psychology } & 14 & 29 & 21 \\ \text { x. Indian psychology } & 4 & 4 & 4 \\ \text { xi. Parapsychology } & 1 & - & 7 \\ \text { xii. Military psychology } & 1 & 1 & - \\ \text { xiii. Psychological measurement } & 45 & 32 & 43 \\ \text { xiv. Abnormal } & 24 & 31 & 29 \\ \text { xv. Projective techniques } & 9 & 14 & 7 \\ \text { xvi. General psychology } & 11 & 9 & 2\end{array}$

Professional Interests

i. Teaching

ii. Pure Research Workers (Ph. D. students included) 39

iii. Persons in Employment doing research (in research institutions included) 34

iv. Persons employed in selection board, Ministry of Defence 6

v. Persons in administration (Some of these are also incluede in teaching or other categories.)

vi. Employed in vocational guidance and counsellin bureaus 55

$\begin{array}{ll}\text { vii. Employed in industry } & 14\end{array}$

viii. Practising psychologists (i.e. working in public or private institutions) 31

IV. The only request I could make to the IUSP is to hold a meeting sometime in one of the Eastern countries in order to give a spurt to psychological activities in the East. July 10, 1963 


\section{INDONESIA}

From Drs. Fouad Hassan, Djakarta:

Dear Prof. Sato,

July 16,1963

Your letter of July 5, 1963, directed to Prof. Slamet Iman Santoso is conveyed to me in order to inform you on those matters you asked for concerning psychological activities in our country.

Of course, we will be glad that you are intending to introduce us to the International Congress; we regret not to be able for the time being to send a delegate of our own, although we wish to have the opportunity to do so.

Since you are leaving soon, I am afraid we are not in time to complete an article on a detailed history of Psychology in Indonesia, however, I will try to do it, if not in time to take it with you to the Congress, then it may be worthwile to put in "Psychologia".

To be clear, the following points may be of some use for you.

1. The training of Psychologists was started in 1952-1953, preceded by the establishment of an Institute of Psychology.

2. The training was subordinated to the Medical Faculty, Univ. of Indonesia in Djakarta, until 1960.

3. In the academic year 1960-1961 the Faculty of Psychology, is detached from above mentioned subordination, and has began a Faculty of its own.

4. The teaching staff consists of Psychologists, who received their training either abroad or at home, or both.

5. The orientation and approach is mainly Continental, although American books are widely used, too. You may say, that the Djakarta school is mainly eclectic, with the stress on sociocultural \& anthropophilosophical approach. To certain extent you may compare this with the phenomenological/exsistential schools in Europe. (With regard to this point I wish to be able to send you another letter on matters of exchange of ideas).

6. Up to the moment there are 40 psychologists in Indonesia, of which 23 are associated with the Faculty of Psychology, Univ. of Indonesia. Another number are mainly members of the armed forces.

7. The degree-system is comparable to the continental schools, i.e. the Drs-degree (Doctorandus), sometimes mistakenly compared as equal to the $M$. A. degree. The Drs-degree is achieved after a complete university study of about 6 years.

8. The professional association is apart from the Faculty, although close contact is maintained between the Indonesian Psychological Association and the Faculty.

9. For reasons of material facilities the Faculty has to set up a limitation with regard to the admission of students for the school. In the past the number is $\mathbf{5 0}$ students admitted yearly, and beginning 1963-1964 we are planning to admit 75 students yearly.

10. At the moment plans are made to start an affiliation (via the Ford Foundation) with one of the established Universities in the U. S., preferably Harvard University. This plan is still quite recently discussed though, so that more concrete and detailed information is still not available.

11. For advanced/post-graduate training we send members of the teaching staff abroad, i. e. to Canada with the Colombo-plan grants and to the U.S. via the A.I.D. 
12. With regard to your question on whether or not we wish to join the International Union is a question to be answered, of course, by the Indonesian Psychological Association. For this reason I convey your question to the Association. Personally I don't see any principal reason why we should not.

These are some points in reply to your letter, we hope to be able to send you a more detailed article on the development of professional psychology in Indonesia.

With best regard and wishes.-

Sincerely,
Drs. Found Hassan,
$\begin{aligned} & \text { Secretary of the Faculty } \\ & \text { of Psychology, University } \\ & \text { of Indonesia, Djakarta }\end{aligned}$

\section{PAKISTAN}

From Professor Q. M. Aslam, La hore:

Dear Profesor Koji Sato,

$16,7,1963$

Thank you very much for your letter of July 5 , which I received the other day.

I am sorry I am late in replying. I had had to shift to Lahore, having retired from Karachi; I am now Professor in Applied Psychology in University of the Panjab, Lahore; which being my new address, I trust you will kindly note. I continue to be proud of my association with "Psychologia".

Regarding your questions, I append brief notes seriatim:

1. We have no national psychological association in Pakistan yet. Psychology is organized at present as a section in our two national organizations viz:

Pakistan Association for the Advancement of Science and Pakistan Philosophical Congress; both head-quartered in Lahore. Psychologists meet in their sections in the annual sessions of these two national associations. It also happens that at least one psychologist (namely myself) is included among the elected Fellows of the Pakistan Academy of Sciences.

2. A move to organize a national psychological association is in a foot. As soon as this takes shape, we will let you know. We would like very much to join the International Union of Scientific Psychology. Kindly request the authorities of the Union to keep us posted about their aims and activities.

3. My estimate of the numbers of teaching psychologists in Pakistan is as follows:

i. In universities and higher education

ii. In teacher-training institutions

iii. In arts colleges

Total

250

A class of professional clinical psychologists is growing.

4. We will address a request to the International Union as soon as we are properly constituted.

5. No other comments.

We appericiate your interest in us.

May I say that I have one or two papers which perhaps you may find suitable for printing in "Psychologia", I shall be sending these to you in the near future. 
I am growing in years, well over 63 already, the oldest psychologist in Pakistan but still working.

With kindest regards.

\author{
Yours sincerely, \\ Prof. Q.M. Aslam \\ Department of Applied Psychology \\ The University of the Panjab
}

\title{
PHILIPPINES
}

From Professor Alfredo V. Lagmay, Quezon City:

Dear Professor Sato,

September 25, 1963

The Psychological Association of the Philippines is now a reality. It was founded late last year and we elected the officers in January, 1963. I became president-elect for this year and using the terminology for this purpose as in the American Psychological Association, I become president of the Association automatically for the year 1964. At the present time we have about 40 members and, this membership promises to become larger by the end of this year. In January, 1964, we shall hold the first psychological convention where it is our plan to schedule the reading of scientific papers. I hope this becomes a tradition from then on.

I am now writing "Psychology in the Philippines" just as I have promised to do. I certainly have not forgotten our conversation on the formation of an Asian Union of Psychologists, which I hope to be able to out with you when I become President of the Association next year.

Very sincerely yours,

Alfredo V. Lagmay

Chairman: Department of Psychology

University of the Philippines

From Dr. Jaime Bulatao, S.J., Manila:

Dear Dr. Koji Sato:

July 28, 1963

Dr. Lagmay transmitted your letter to me as executive secretary of the Psychological Association of the Philippines for a reply.

1. On November 15,1962, we founded the first professional association for psychologists in the Philippines and gave it the name Psychological Association of the Philippines. It is now incorporated under Philippine Law. We have met regularly once a month at the University of the Ateneo de Manila to listen to psychological papers and to discuss the problems of psychology in the Philippines. We now have 37 members of whom 12 have $\mathrm{Ph}$. D's and the rest, M.A.'s. We have also several student affliates who still are not members but hope to be members in the future. This year's officers are the following: President - Dr. Sinforoso Padilla, Vice-President and President Elect - Dr. Alfredo Lagmay, Executive Secretary - Dr. Jaime Bulatao, S.J., Treasurer - Dr. Estefania Aldaba-Lim.

We have established relationships with various other scientific groups, mainly the group for the advancement of Psychiatry in the Philippines and the Philippine Sociological Society. At the moment, we are in the process of planning the first Psychological Convention in the 
Philippines which will be held in the early part of February, 1964. A call of papers has been sent out and responsibility for the various divisions has been assigned. The activity centers mainly around three universities: University of the Philippines, Ateneo de Manila, and the Philippine Women's University. One of the main aims of our associations has been to establish Psychology as a profession in the Philippines, clearly delineating who has the right to be called a psychologist, in contrast with past conditions where doctors of medicine or even philosophers refer to themselves as psychologists.

2. With regard to your question whether or not we are interested in joining the International Union of Psychology, the Board asked me to transmit to you its interest in joining. May we have further information regarding the International Union as well as application blanks?

3. The number of psychologists given above as members of the PAP include practically all the psychologists in the country with the probable exemption of three or four who have failed to join.

4. As for requests to the International Union from the Philippines, a suggestion was made by the Board to ask your Union to notify us whenever one of your member will be passing by the Philippines. We shall whenever possible extend our association's hospitality to such members.

5. A question has been raised on the possibility of extending some kind of a Peace Corps among psychologists. For the time being, the Philippines would be on the receiving end. We need psychologists to help us catch up with the Western World. Perhaps we could get volunteers to join our universities for two or three years. We may soon be producing a larger number of qualified psychologists who can then spread out to the other nations of the East.

We thank you for your interest and we hope that your conference will be a success.

Sincerely yours,

Jaime Bulato, S. J., Ph. D.

Executive Secretary

Psychological Association of the Philippines P.O. Box 154, Manila

PARTICIPANTS OF THE FOLLOWING DISCUSSION (p.183-186)

HISAMATSU, Shin-ichi Professor of Hanazono Zen College, Kyoto, formerly Professor of Kyoto University (Buddhism) and Kyoto City College of Fine Arts (Philosophy). Author of "Zen and Fine Arts," "Oriental Nothingness," "Way of Absolute Subjectivity." Visited the United States and Europe in 1958 - 1959 and lectured at Harvard Divinity School and other institutions.

NISHITANI, Keiji Professor of Philosophy, Otani University, Kyoto, formerly Professor of Kyoto University (Philosophy of Religion). Studied in Germany before the War. Author of "On Religion," "Nihilism," "Philosophy of Fundamental Subjectivity" and other books.

DEMARTINO, Richard Lecturer at Otani University (1963 - 1965 Visiting Lecturer at Temple University, Philadelphia). Author of "The Human Situation and Zen Buddhism" in "Zen Buddhism and Psychoanalysis."

KATAOKA, Hitoshi Professor of Educational Guidance, Kyoto University.

SATO, Koji Professor of Psychology, Kyoto University. Editor: Psychologia. Author of "Psychology of Personality," "Psychology of Zen," "Ki and Morale" and other books.

TOYOMURA, Sachi Lecturer at Ikenobo Flower Arrangement Institute, Kyoto. Studied in the United States and France after the War. Editorial Assistant: Psychologia. 